\title{
Morphometric and genetic assessment of the Cynoscion guatucupa population structure from Buenos Aires coast, Argentine Sea
}

Evaluación morfométrica y genética de la estructura poblacional de Cynoscion guatucupa de la costa de Buenos Aires en el Mar Argentino

\section{David E. Sabadin ${ }^{1}$, Mariano González-Castro ${ }^{2}$, Celia Iudica ${ }^{3}$, Juan M. Díaz de Astarloa ${ }^{2}$ and Pedro J. Fernández-Iriarte ${ }^{1}$}

\author{
${ }^{1}$ Laboratorio de Genética, Departamento de Biología, Facultad de Ciencias Exactas y Naturales, Universidad Nacional de Mar \\ del Plata, Funes 3250, 7600 Mar del Plata, Argentina, CONICET. firiarte@mdp.edu.ar \\ ${ }^{2}$ Laboratorio de Ictiología, Departamento de Ciencias Marinas, Facultad de Ciencias Exactas y Naturales, Universidad Nacional \\ de Mar del Plata, Funes 3250, 7600 Mar del Plata, Argentina, CONICET \\ ${ }^{3}$ Asociación de Genética Humana, Colón 3853 (7600), Mar del Plata, Argentina
}

\begin{abstract}
This study analyzed the morphometric, microsatellite loci and mitochondrial control region variation of the striped weakfish from two feeding and spawning grounds in the coastal area of Buenos Aires province. The characterization of the body shape proved to be different between sites. Genetic structure analysis showed that the main source of genetic variation was within populations rather than among populations and low genetic differentiation was observed between sites. The striped weakfish inhabiting the coastal areas of Buenos Aires would exhibit two management units in agreement with other fishes studied in both areas.
\end{abstract}

Key words: Genetic structure, body shape, microsatellites, conservation

\section{INTRODUCTION}

The distribution pattern of genetic population structure, within and among populations is a key aspect in the field of conservation genetics of fish. This is crucial to identify evolutionary and management units, which are defined as groups of individuals exhibiting substantial reproductive isolation or adaptive divergence or both (Crandall et al. 2000). Management units, in turn, are understood as groups of individuals among which the extent of ecological and genetic connectivity is sufficiently low, and hence each group (subpopulation or stock) must be individually monitored and managed (Laikre et al. 2005, Palsbøll et al. 2006). The ability to identify management units or the possibility of establishing genetic differentiation or discontinuity among evolutionary units in nature depends on the species life history and ecology (Waples 1998). The factors and main processes responsible for promoting genetic differentiation or genetic and/or ecological discontinuities among marine populations are: historical vicariance, limited dispersal ability (philopatry), larval retention, local adaptation, and barriers to gene flow, such as oceanographic fronts (salinity and temperature, among others) and habitat discontinuity (seabed type) (Riginos \& Nachman 2001).
The coastal fish species of the Argentine Sea have shown evidence of overexploitation and signs of capture decrease and smaller individuals, which could be affecting the species survival (Ruarte et al. 2004). In this framework, the need to adopt monitoring measures through molecular markers as a key tool in management decision taking (Ward 2000). However, studies conducted on genetic structure using microsatellite loci in the Argentine Sea have been scarce (Beheregaray \& Sunnucks 2001), even if the scientific community has recognized the need to address diversity and genetic structure of marine fish populations (Palumbi 2003, Laikre et al. 2005). Likewise, it is worth highlighting the fact that molecular tools are more effective when combined with other approaches, including morphometric, oceanographic, tagging and recapture data, as well as life history variables and ecological models, among others (Ward 2000).

The present study focused on the striped weakfish Cynoscion guatucupa (Cuvier, 1830) (Actinopterygii, Sciaenidae) which is a wide spread demersal fish in South America, ranging from the coast of Rio de Janeiro, Brazil $\left(22^{\circ} \mathrm{S}\right)$, to the coasts of Chubut province, Argentina $\left(43^{\circ} \mathrm{S}\right)$ (Cousseau \& Perrotta 2004). In Argentina, it ranks second 
in commercial importance in the Buenos Aires coastal area $\left(36^{\circ} \mathrm{S}\right.$ to $\left.41^{\circ} \mathrm{S}\right)$. Argentine landings of striped weakfish come from catches from Samborombón Bay, part of the Argentine-Uruguayan Common Fishing Zone (AUCFZ) $\left(34^{\circ} \mathrm{S}\right.$ to $\left.39^{\circ} \mathrm{S}\right)$, and from El Rincón zone to the South of Buenos Aires province $\left(39^{\circ} \mathrm{S}\right.$ to $41^{\circ} \mathrm{S}$ ) (Ruarte et al. 2004).This study aims to provide a comparative analysis between morphometrics based on landmarks, microsatellite loci and control region variation from two fishing sites in the Buenos Aires coast, wherein the striped weakfish is caught: Samborombón Bay and El Rincón.

\section{Material And Methods}

\section{STUDY AREA}

The sampling comprised two spawning, feeding and nursery grounds of striped weakfish from the Argentine Sea: Samborombón Bay $\left(36^{\circ} \mathrm{S} ; 56^{\circ} \mathrm{W}\right)$ and El Rincón zone $\left(39^{\circ} 05^{\prime} \mathrm{S} ; 61^{\circ} \mathrm{W}\right)$ (Fig. 1). Fish were caught by trawl during feeding time (June and July 2008), frozen upon capture and taken immediately to the laboratory. A total of 57 individuals were collected from Samborombón Bay and 75 from El Rincón. Specimens were weighed, sexed, and assessed for gonad maturation stage. Muscle tissue samples were taken from the body and stored in plastic microtubes with ethanol or frozen.

\section{MORPHOMETRIC ANALYSIS}

Twenty-one morphometric variables were analyzed on the left flank of 132 specimens, based on 10 anatomical landmarks placed in 4 quadrilaterals («Box Truss») obtained in line with the Truss Network protocol (Strauss \& Bookstein 1982) (Fig. 2). The variables analyzed were as follows: 1-2, 1-3, 1-4, 2-3, 2-4, 3-4, 3-5, 3-6, 4-5, 4-6, 5-6, 5-7, 5-8, 6-7, 6-8, 7-6, 7-8, 7-9, 8-9, 8-10, 9-10 (Fig. $2)$. Interlandmark distances were obtained from fresh specimens, using a digital caliper of $0.01 \mathrm{~mm}$ accuracy. After normalization (Lleonart et al. 2000), a Principal Component Analysis (PCA) was conducted to detect shape variations between sampling sites. PCA and Discriminant Analysis were computed using XLSTAT software.

\section{GeNETIC ANALYSIS}

DNA was isolated using Chelex extraction method (Estoup et al. 1996). Polymerase chain reaction (PCR) was used to amplify 2 microsatellite loci: CacMic18 and CacMic19 which had yielded good results in the cross-species amplification between C. striatus (now C. guatucupa) and C. acoupa (Farias et al. 2006). Primers, amplifications and PCR conditions were described in Farias et al. (2006). PCR products were genotyped by denaturing polyacrylamide gel electrophoresis 6\% (19:1 acrylamide: bisacrylamide) and visualized by silver nitrate staining.

The mean number of alleles per locus, observed heterozygosity (Ho) and expected heterozygosity (He) were estimated using GENEPOP 4.0 software (Rousset 2008). Probability tests for Hardy-Weinberg equilibrium (HWE) in each region (by locus and multilocus), and for linkage disequilibrium between loci were performed using GENEPOP. Whenever the genotype frequencies observed

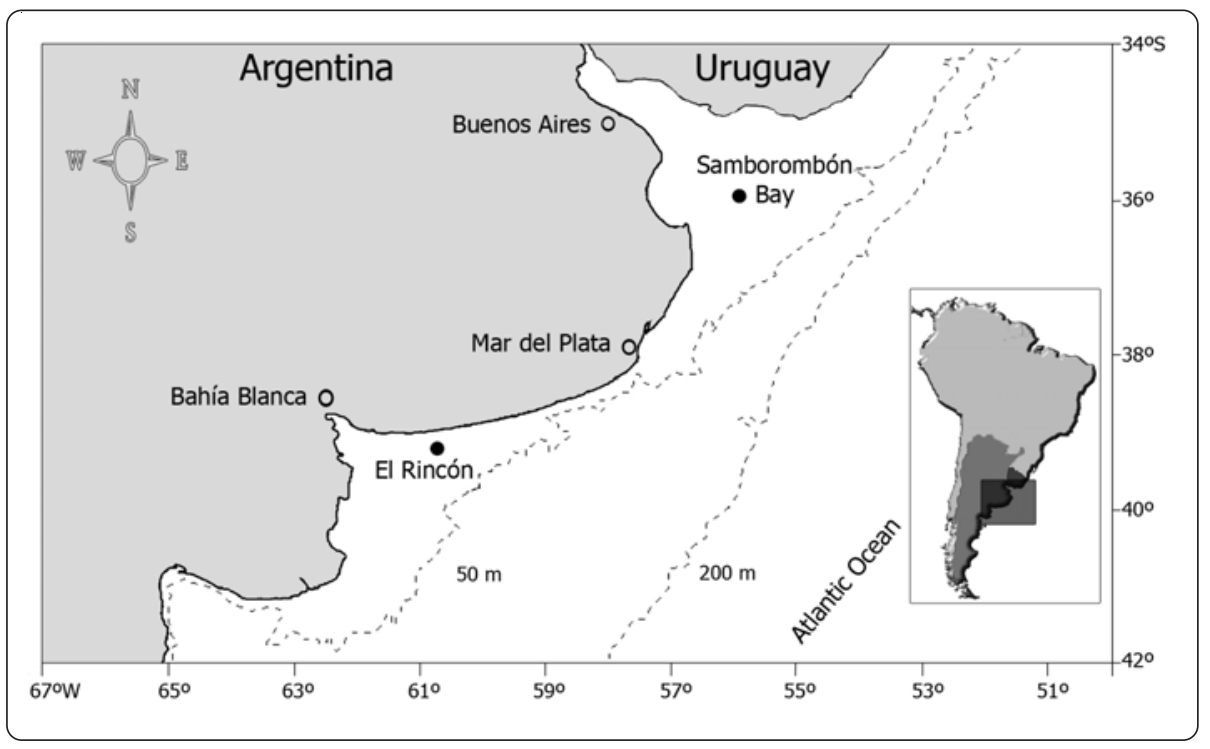

Figure 1. Map showing the study area and sampling sites $(\bullet)$ of Cynoscion guatucupa at Samborombón Bay and El Rincón / Mapa del área de estudio indicando los sitios de muestreo $(\bullet)$ de Cynoscion guatucupa en la Bahía Samborombón y en El Rincón 


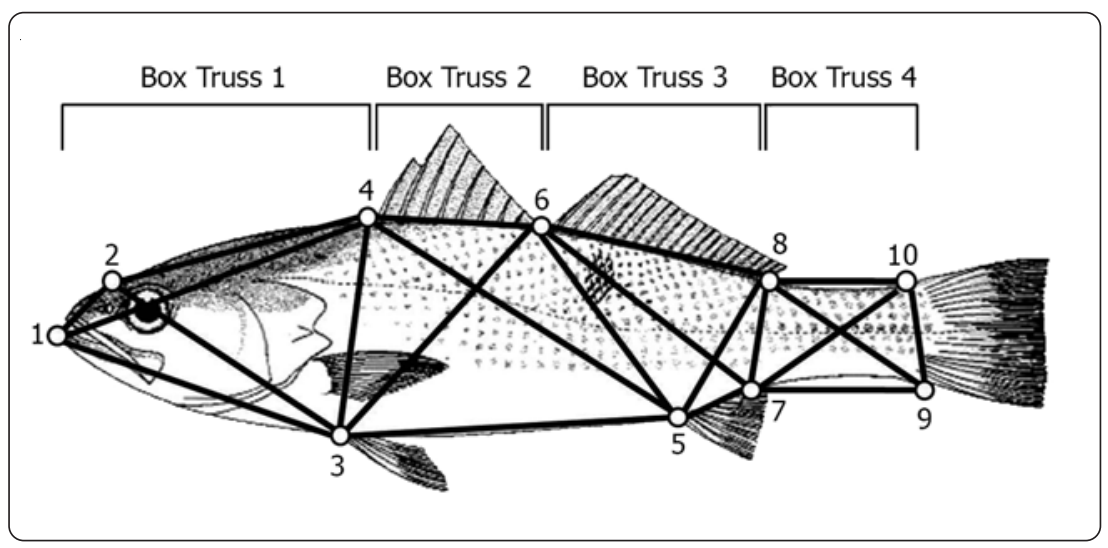

Figure 2. Location of the 10 anatomical landmarks with the corresponding 'Box Truss' of Cynoscion guatucupa / Localización de los 10 'landmarks' anatómicos de Cynoscion guatucupa con su correspondiente 'Box Truss'

deviated significantly from HWE, MICROCHECKER analysis (Oosterhout et al. 2004) was applied to determine the most probable cause among various genotyping errors and the presence of null alleles. A maximum likelihood estimate of null allele frequency was then calculated for each locus and population using FREENA software (Chapuis \& Estoup 2007). A hierarchical analysis of molecular variance (AMOVA) among and between sites was conducted as well. It was tested by 10,000 permutations using the computer package ARLEQUIN 3.11 (Schneider et al. 2000). The genetic differentiation between sites was analyzed by estimating the $\mathrm{F}_{\mathrm{ST}}$ index, and the statistical significance was examined by performing permutation tests implemented in FSTAT (Goudet 2001). Likewise the method implemented in FREENA for estimating $\mathrm{F}_{\mathrm{ST}}$ in the presence of null allele was adopted.

A partial sequence of the mitochondrial control region was amplified using primers and the PCR conditions described by Beheregaray \& Sunnucks (2001). The PCR product was purified and sequenced in MACROGEN (Korea). The sequences were manually aligned applying PROSEQ 3.0 (Filatov 2002) and the differentiation between sites was analyzed by estimating the $\phi_{\mathrm{ST}}$ parameter using ARLEQUIN 3.11 (Schneider et al. 2000).

\section{Results AND Discussion}

In Cynoscion guatucupa, eight alleles were detected for the CacMic18 loci, whereas for CacMic19, eleven alleles were observed. At both sampling locations, microsatellite loci exhibited high expected heterozygosity (0.835 in Samborombón; 0.831 in El Rincón) and low observed heterozygosity (0.402 in Samborombón; 0.396 in El
Rincón), with a mean of 10 alleles per locus. Highly significant departures from Hardy-Weinberg expectation were recorded for each locus, such as in the multilocus analysis conducted at each sampling location, which yielded homozygote excess $\left(\mathrm{F}_{\mathrm{IS}}=0.528, P<0.001\right.$ in Samborombón; $\mathrm{F}_{\mathrm{IS}}=0532, P<0.001$ in El Rincón). On the other hand, the MICROCHECKER analysis suggested the presence of null alleles in both loci with similar frequency between them (CacMic18: 0.253 in Samborombón and 0.228 in El Rincón, and CacMic19: 0.225 in Samborombón and 0.244 in El Rincón), as well as the mean allele frequency in all populations and loci (0.238).

The main explanations for such homozygote excess are null alleles and Wahlund effect. Loci CacMic18 and CacMic19 contain null alleles which most probably originate from poor cross-species PCR amplification. This is most likely explained by the mutations taking place in the priming site(s) of C. guatucupa, since $24 \%$ of the alleles failed to amplify, and being microsatellites containing 8 alleles or more, most individuals should be heterozygotes. Likewise, when comparing both sampling locations, AMOVA revealed that the main variation source was within the fishing sites (99\%) (SS=126.703; d.f. = 190; Variance $=0.667)$ rather than between locations $(1 \%)(\mathrm{SS}=1.297$; d.f. $=1$; Variance $=0.007$ ) displaying no other differences than those expected by random $(P>0.05)$. Population differentiation between sampling locations yielded low $\mathrm{F}_{\mathrm{ST}}$ values for CacMic18 $\left(\mathrm{F}_{\mathrm{ST}}=0.0001, P>0.05\right)$ and for multilocus $\left(\mathrm{F}_{\mathrm{ST}}=0.0109, P>0.05\right)$. With respect to locus CacMic19, the index was low but differed significantly $\left(\mathrm{F}_{\mathrm{ST}}=0.0210, P<0.05\right)$. In the same way the estimation of $\mathrm{F}_{\mathrm{ST}}$ per locus using the correction for null alleles (ENA) was lower than the uncorrected $\mathrm{F}_{\mathrm{ST}}$ for CacMic18 $\left(\mathrm{F}_{\mathrm{ST}}\right.$ ENA 
$=-0.0002)$, for CacMic19 $\left(\mathrm{F}_{\mathrm{ST}} \mathrm{ENA}=0.0128\right)$ as well as for multilocus $\left(\mathrm{F}_{\mathrm{ST}} \mathrm{ENA}=0.0069\right)$. In addition, the sequence of $365 \mathrm{bp}$ obtained from the control region for 47 individuals from Samborombón Bay $(\mathrm{n}=22)$ and from El Rincón ( $\mathrm{n}=25)$, showed a low genetic differentiation index that not differed significantly between sampling sites $\left(\phi_{\mathrm{ST}}=-0.0172, P>0.05\right)$. This pattern of genetic structure could be attributed to high recent and historical gene flow. The low genetic differentiation values can be explained by panmixia between populations or by different lineages which have recently diverged and so changes cannot be detected (Waples 1998, Palumbi 2003). Nonetheless, conclusions should be drawn with caution in this case, as this study only explored two microsatellite loci.

The characterization of the striped weakfish body shape indicated a clear differentiation among individuals from both sampling sites (Fig. 3). The three first axes of the PCA accounted $60 \%$ of the total variance in the data. Those from Samborombón Bay were mainly located in the first and fourth quadrant, while those from El Rincón were found in the second and third one (Fig. 3). The individuals from Samborombón Bay displayed higher values than the mean for 3-4, 3-6, 4-5, 5-6, 5-8, 6-7, and 9-10 variables, corresponding to 'Box Truss' 2 and 3 and, to a lesser extent, to 'Box Truss' 4. The individuals from El Rincón, in turn, displayed lower values than the mean for 8-10 and 7-9 variables and higher for 1-2, 1-4, and 2-4, corresponding to 'Box Truss' 4 and, to a lesser extent, to 'Box Truss' 1. The Discriminant Analysis of the morphometric variation using the normalized data yielded highly significant differences between both sampling locations (Wilks' lambda $\left.=0.238, \mathrm{~F}_{(21,110)}=16.76, P<0.001\right)$. This indicates that individuals from Samborombón Bay exhibited higher and more robust bodies, while those from El Rincón featured greater length and lesser height of the caudal fin.

These results contribute to the differentiation of individuals from the northern coast of Buenos Aires province with respect to those from the southern coast of El Rincón (Díaz de Astarloa \& Bolasina 1992, Volpedo \& Fernández-Cirelli 2006) and constitute a new indicator of the presence of more than one management unit in this distribution area. The differentiation in management units between the individuals of C. guatucupa from Samborombón Bay and El Rincón zone, in agreement with other fishes studied in both areas (Braicovich \& Timi 2008, Timi et al. 2009), could be associated with the fact that the waters from both fishing sites display notorious oceanographic differences (Acha et al. 2004). The individuals from Samborombón Bay and El Rincón fishing sites showed low genetic differentiation (microsatellites and control region). However, the different morphological patterns noticed in the sampling locations would allow identifying local differentiation processes, thereby suggesting the existence of at least two management units for the striped weakfish in the Argentine Sea.

\section{ACKNOWLeDgments}

The authors gratefully thank Dr. Izeni P. Farias for kindly providing the primers of Cynoscion acoupa. We wish to thank two anonymous reviewers for valuable suggestions. This work was supported by the following grants: PIP 6357

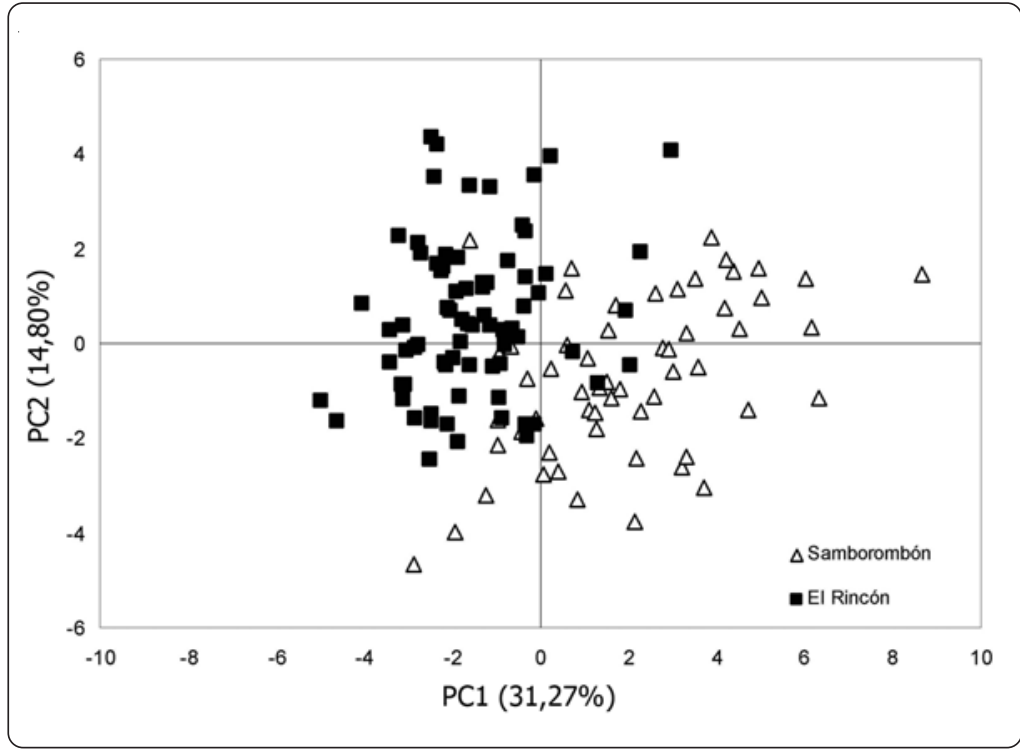

Figure 3. Principal Component (PC1 vs. PC2) based on landmarks at Cynoscion guatucupa from Samborombón Bay and EI Rincón / Componentes Principales (CP1 vs. CP2) basado en los landmarks de Cynoscion guatucupa en Bahía Samborombón y El Rincón 
(CONICET), PIP 2504 (CONICET) and 15/E398 (UNMdP) awarded to P.F.I., M.G.C. and J.M.D.A. are members of the Scientific Researcher Program of CONICET (Argentina).

\section{LITERATURE CITED}

Acha EM, HM Mianzan, RA Guerrero, M Favero \& J Bava. 2004. Marine fronts at the continental shelves of austral South America physical and ecological processes. Journal of Marine System 44: 83-105.

Beheregaray LB \& P Sunnucks. 2001. Fine-scale genetic structure, estuarine colonization and incipient speciation in the marine silverside fish Odontesthes argentinensis. Molecular Ecology 10: 2849-2866.

Braicovich PE \& JT Timi. 2008. Parasites as biological tags for stock discrimination of the Brazilian flathead Percophis brasiliensis in the south-west Atlantic. Journal of Fish Biology 73: 557-571.

Chapuis MP \& A Estoup. 2007. Microsatellite null alleles and estimation of population differentiation. Molecular Biology and Evolution 24: 621-631.

Cousseau MB \& RG Perrotta. 2004. Peces marinos de Argentina. Biología, distribución, pesca, 167 pp. Instituto Nacional de Investigación y Desarrollo Pesquero, Mar del Plata.

Crandall KA, ORP Bininda-Emonds, GM Mace \& RK Wayne. 2000. Considering evolutionary processes in conservation biology. Trends in Ecology \& Evolution 15: 290-295.

Díaz de Astarloa JM \& SN Bolasina. 1992. Análisis estadístico de los caracteres morfométricos y merísticos de la pescadilla de red (Cynoscion striatus) en el área comprendida entre $34^{\circ}$ y 39³0’ S. Frente Marítimo 11: 57-62.

Estoup A, CR Largiadèr, E Perrot \& D Chourrout. 1996. Rapid one-tube DNA extraction for reliable PCR detection of fish polymorphic markers and transgenes. Molecular Marine Biology and Technology 5: 295-298.

Farias IP, LB Muniz, S Astolfi-Filhot \& I Sampaio. 2006. Isolation and characterization of DNA microsatellite primers for Cynoscion acoupa, the most exploited sciaenid fish along the coast of Brazil. Molecular Ecology Notes 6: 660-663.

Filatov DA. 2002. PROSEQ: A software for preparation and evolutionary analysis of DNA sequence data sets. Molecular Ecology Notes 2: 621-624

Goudet J. 2001. FSTAT, a program to estimate and test gene diversities and fixation indices, Version 2.9.3. [on-line] $<$ http://www2.unil.ch/popgen/softwares/fstat.htm>
Laikre L, S Palm \& N Ryman. 2005. Genetic population structure of fishes: implications for coastal zone management. Ambio 34: 111-119.

Lleonart J, J Salat \& GJ Torres. 2000. Removing allometric effects of body size in morphological analysis. Journal of Theoretical Biology 205: 85-93.

Oosterhout CV, WF Hutchinson, DPM Wills \& P Shipley. 2004. Micro-Checker: software for identifying and correcting genotyping errors in microsatellite data. Molecular Ecology Notes 4: 535-538.

Palsbøll PJ, M Bérubé \& FW Allendorf. 2006. Identification of management units using population genetic data. Trends in Ecology and Evolution 22: 11-16.

Palumbi SR. 2003. Population genetics, demographic connectivity and the design of marine protected areas. Ecological Applications 13: 146-158.

Riginos C \& MW Nachman. 2001. Population subdivision in marine environments: the contributions of biogeography, geographical distance and discontinuous habitat to genetic differentiation in a blennioid fish, Axoclinus nigricaudus. Molecular Ecology 10: 1439-1453.

Rousset F. 2008. GENEPOP'007: a complete reimplementation of the GENEPOP software for Windows and Linux. Molecular Ecology Resources 8: 103-106.

Ruarte C, C Lasta \& C Carozza. 2004. Pescadilla de red (Cynoscion guatucupa). In: Boschi E (ed). El mar argentino y sus recursos pesqueros 4: 271-281. Instituto Nacional de Investigación y Desarrollo Pesquero, Mar del Plata.

Schneider S, D Roessli \& L Excoffier. 2000. Arlequín Software for population genetics data analysis, Version 2.000, Geneva, Switzerland. [CD ROM]

Strauss BE \& FL Bookstein. 1982. The Truss: Body form reconstructions in morphometrics. Systematic Zoology 31: 113-135.

Timi JT, AL Lanfranchi \& JA Etchegoin. 2009. Seasonal stability and spatial variability of parasites in Brazilian sandperch Pinguipes brasilianus from the Northern Argentine Sea: evidence for stock discrimination. Journal of Fish Biology 74: 1206-1225.

Volpedo AV \& A Fernández-Cirelli. 2006. Otolith chemical composition as a useful tool for sciaenids stock discrimination in south-western Atlantic. Scientia Marina 70: 325-334.

Waples RS. 1998. Separating the wheat from the chaff: patterns of genetic differentiation in high gene flow species. Journal of Heredity 89: 438-450.

Ward RD. 2000. Genetic in fisheries management. Hydrobiologia 420: 191-201.

Recibido el 11 de febrero de 2010 y aceptado el 24 de junio de 2010 